\title{
TOXICOLOGICAL INVESTIGATIONS ON DIMETHYLFORMAMIDE
}

\author{
BY \\ W. MASSMANN \\ From the Akademie für Sozialhygiene, Arbeitshygiene und ärztliche Fortbildung, Berlin-Lichtenberg
}

(RECEIVED FOR PUBLICATION JUNE 24, 1955)

Dimethylformamide is the only solvent from which it is possible to spin the polymer polyacrylonitrile for the production of "orlon" fibre. Because nothing was known of its biological properties and workers making polyacrylonitrile fibres come into contact with it, an examination of its toxicity was undertaken.

\section{Chemical Properties}

Dimethylformamide is a colourless liquid with the formula :-<smiles>CN(C)C=O</smiles>

The boiling point is $153^{\circ} \mathrm{C}$., and it is miscible with water and some organic solvents. On boiling with water or alkali it hydrolyzes to formic acid and dimethylamine. It is more stable than formamide and can be distilled. For the present work freshly distilled dimethylformamide was used and all aqueous solutions were freshly prepared.

Dimethylformamide in the atmosphere may be trapped by passing the air through two bubblers containing water and estimating it by the method of Bergmann (1952). Of a dimethylformamide solution, $10 \mathrm{ml}$. was mixed with $1 \mathrm{ml} .3 \cdot 5 \mathrm{~N}-\mathrm{NaOH}$ and $1 \mathrm{ml}$. $2 \mathrm{~N}$-hydroxylamine sulphate. After shaking, it was left at $15^{\circ} \mathrm{C}$. for four hours and $1 \mathrm{ml}$. of $3.5 \mathrm{~N}-\mathrm{HCl}$ and $0.74 \mathrm{M}-\mathrm{FeCl}_{3}$ added and the colour estimated. It may be estimated directly in blood after precipitating the proteins or in filtrates of urine or stomach contents.

\section{Toxicology}

Acute Toxicity.-The L.D.50 was determined by the method of Kärber (1931) using seven animals per dose. Albino mice (18 to $23 \mathrm{~g}$.), albino rats ( 180 to 220 g.), rabbits, and cats were used after 12 hours' starvation. They were observed for 21 days. Using 49 mice given intraperitoneal injections, the L.D.50 was found to be $0.3 \mathrm{ml}$. dimethylformamide $/ 100 \mathrm{~g}$. The greatest tolerated dose was $0.05 \mathrm{ml}$. and the certain lethal dose (L.D.100) $0.6 \mathrm{ml}$.

The results on rats are presented in Table 1. Over a 24-hour observation period the L.D.50 for rats by subcutaneous injection was $0.78 \mathrm{ml} . / 100 \mathrm{~g}$.

TABLE 1

THE ACUTE TOXICITY OF DIMETHYLFORMAMIDE TO RATS

\begin{tabular}{|c|c|c|c|c|c|}
\hline Route & $\begin{array}{c}\text { No. } \\
\text { of } \\
\text { Ani- } \\
\text { mals }\end{array}$ & $\begin{array}{l}\text { Maxi- } \\
\text { mum } \\
\text { Tole- } \\
\text { rated }\end{array}$ & L.D.50 & L.D.100 & $\begin{array}{c}\text { Survival } \\
\text { Time }\end{array}$ \\
\hline $\begin{array}{l}\text { Intraperitoneal } \\
\text { Subcutaneous } \\
\text { Oral . . . . }\end{array}$ & $\begin{array}{l}42 \\
56 \\
56\end{array}$ & $\begin{array}{l}0.01 \\
0 \cdot 10 \\
0 \cdot 10\end{array}$ & $\begin{array}{l}0 \cdot 14 \\
0.38 \\
0.37\end{array}$ & $\begin{array}{l}0.40 \\
0.80 \\
0.80\end{array}$ & $\begin{array}{l}6 \mathrm{hr} .-10 \text { days } \\
6 \mathrm{hr}-6 \text { days } \\
12 \mathrm{hr}-12 \text { days }\end{array}$ \\
\hline
\end{tabular}

Dose $\mathrm{ml} . / 100 \mathrm{~g}$. body weight.

After the injection some animals appeared to be anaesthetized and then died rapidly or recovered in less than two hours to die later. Apart from some general apathy the animals showed little else except a loss of appetite which was sometimes complete and an accompanying loss of weight. Tremors, convulsions, and paralyses were never seen.

The results on cats and rabbits injected intraperitoneally are presented in Table 2.

TABLE 2

THE ACUTE TOXICITY OF DIMETHYLFORMAMIDE GIVEN INTRAPERITONEALLY TO CATS AND RABBITS

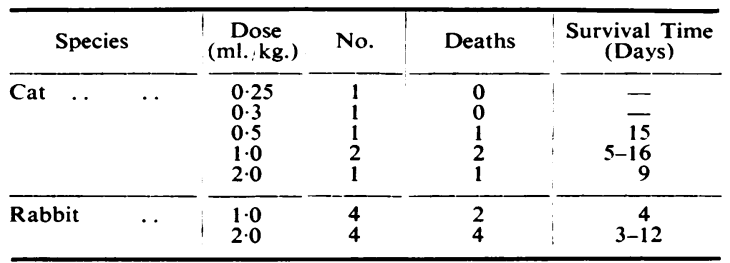


Groups of seven fish (Rhodeus amarus) were placed in solutions of dimethylformamide for 24 hours and then put back into freshly aerated water and observed for 21 days. A $0.1 \%$ solution of dimethylformamide had no effect; $0.5 \%$ dimethylformamide had no immediate effect but two fish died during the next 15 days. In $1 \%$ dimethylformamide the fish were slightly uncoordinated after 30 minutes. After two hours two fish lay on their sides and one died after four hours. After eight days five of the six survivors had died.

Skin Absorption.-Rats' tails were dipped in concentrated dimethylformamide solutions at $40^{\circ} \mathrm{C}$. for eight hours. Considering the tails as cylinders the area exposed was calculated to be 13.9 to $14.2 \mathrm{~cm}^{2}$. of skin for the rats of 160 to $220 \mathrm{~g}$. The tails were rinsed after exposure but became tanned and mummified in a few days. Groups of seven rats were exposed to $25,50,75$, and $100 \%$ concentrations. All those exposed to $100 \%$ dimethylformamide died in one to four days after losing 10 to $30 \mathrm{~g}$. body weight. Two of the seven rats exposed to $75 \%$ died. The others lost weight during the first few days and then regained it. None of the other rats died. It was calculated that at least $0.8 \mathrm{ml}$. of $100 \%$ dimethylformamide had been absorbed through $14 \mathrm{~cm}^{2}$. of skin.

Pathological Findings.-No changes in the red or white blood cells of cats and rabbits were observed and the sternal marrow was normal. In one rabbit and one cat which died the haemoglobin fell.

The blood sugar level in cats and rabbits rose after the intraperitoneal injection of dimethylformamide and hyperglycaemia might be maintained for up to 24 hours (Fig. 1). Glucose tolerance tests on rabbits were normal.

The urines of both cats and rabbits were acid, and during the hyperglycaemic phase sugar appeared in the urine. The urine deposit was normal and albuminuria was not observed. The E.C.G. of

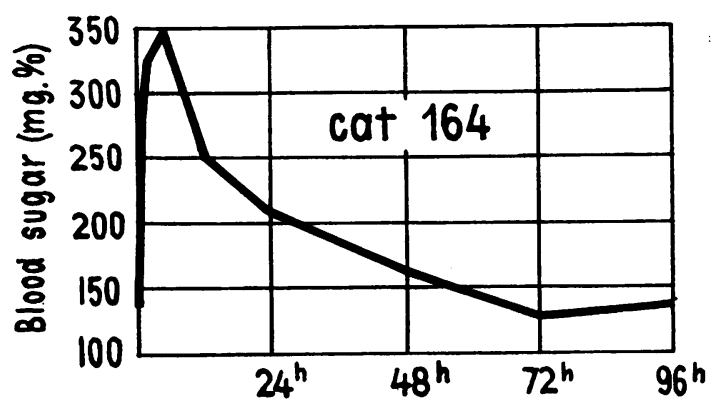

FIG. 1.-The blood sugar curve of a cat injected with $2 \mathrm{ml}$. dimethylformamide/kg. poisoned cats was abnormal for several days or until death.

Necropsies were performed on all animals that died and of every group the organs of three were examined histologically. The most striking and consistent lesions were in the liver which in rabbits and cats was reduced in size and clay coloured. In six of eight animals examined there was fatty degeneration of the liver cells with widespread necroses (Figs. 2 and 3). The stomach, lungs, heart, spleen, kidney, suprarenals, pancreas, and brain showed no consistent changes.

Chronic Toxicity.-Groups of two cats and 16 rats were put in a gas-tight chamber $\left(0.6 \mathrm{~m}^{3}\right.$.) for eight hours daily except Sundays for up to 120 days. Ventilation was at the rate of 180 to $2001 . / \mathrm{hr}$. and in three experiments the air contained 100, 230, and 450 p.p.m. dimethylformamide. Two analyses were carried out each day. Each week the animals were weighed and every two weeks the blood was examined, an E.C.G. taken, and liver function tests carried out on the cats.

At the highest concentrations of dimethylformamide the cats ate badly and lost weight but no other signs were observed. All the rats grew normally and appeared unaffected.

Some rats were killed during the experiment and at the end all the cats and three more rats were examined. An irregular incidence of liver necrosis similar to that seen in the acute experiments was observed in the rats despite their normal outward appearance. In the cats fatty degeneration but no necrosis was seen in the livers.

Bronchopneumonic changes were observed in some animals. Hyperaemia of the brain, cloudy swelling of the uriniferous tubules of the kidney, and iron deposits in the spleen were also recorded. During life the blood picture, urine, and E.C.G. remained normal.

Metabolism of Dimethylformamide.-Repeated small doses of dimethylformamide were injected every three minutes intravenously into fasting anaesthetized cats until a total of $6 \mathrm{ml}$. had been given. Previously the trachea had been cannulated and the pylorus of the stomach tied. All expired air was passed through a bubbler to trap the dimethylformamide. Two hours after the last injection the cats were killed. The stomach contents, expired air, and urine formed were analysed for dimethylformamide and also for formic acid and dimethylamine. Neither of the last two was detected. The total quantities of dimethylformamide recovered are given in Table 3. 


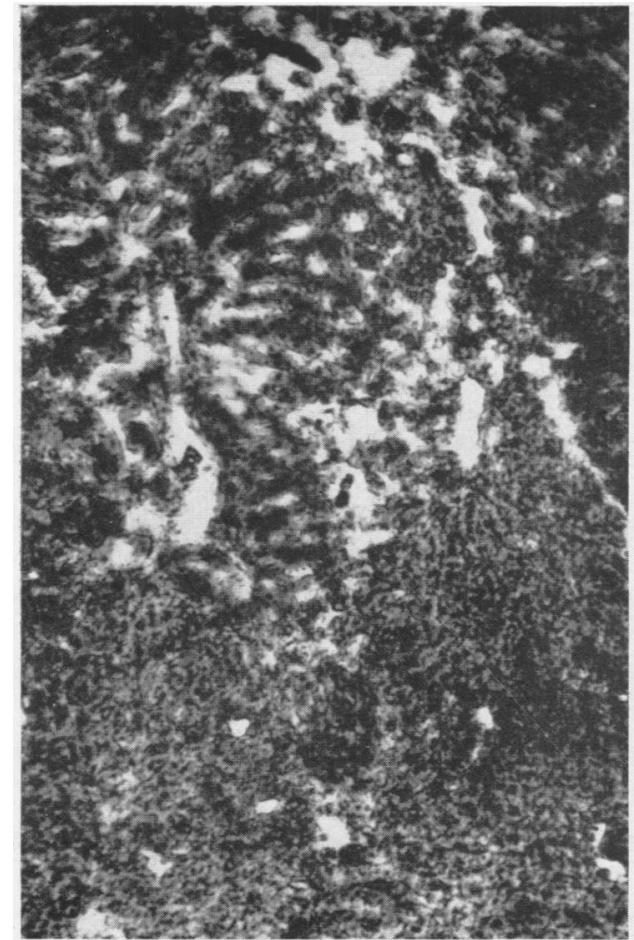

FIG. 2.- The liver of a rat two days after $0.15 \mathrm{ml}$.dimethylformamide $100 \mathrm{~g}$. intraperitoneally. Extensive haemorrhages with necroses of the remaining liver cells. $\times 19$.

TABLE 3

DIMETHYLFORMAMIDE RECOVERED FROM CATS AFTER REPEATED INTRAVENOUS INJECTION OF SMALL DOSES TO A TOTAL OF $6 \mathrm{ML}$.

\begin{tabular}{|c|c|c|c|c|}
\hline \multirow{2}{*}{$\begin{array}{c}\text { Cat } \\
\text { Weight } \\
\text { (kg.) }\end{array}$} & \multicolumn{4}{|c|}{ Dimethylformamide (mg.) Recovered } \\
\hline & Urine & $\begin{array}{c}100 \mathrm{ml} . \\
\text { Blood }\end{array}$ & Stomach & $\underset{\text { Air }}{\text { Expired }}$ \\
\hline $\begin{array}{l}2.9 \\
3.8 \\
4.7\end{array}$ & $\begin{array}{r}16.5 \\
12.8 \\
8.9\end{array}$ & $\begin{array}{l}3 \cdot 7 \\
3 \cdot 1 \\
5 \cdot 0\end{array}$ & $\begin{array}{l}6.0 \\
7.8 \\
9.2\end{array}$ & $\begin{array}{l}0 . \overline{1} \\
0.04\end{array}$ \\
\hline
\end{tabular}

Within 24 hours of a dose of 1 to 2 ml. dimethylformamide $/ \mathrm{kg}$. body weight rabbits excreted 10 to $15 \%$ in the urine.

Action on Skin and Mucous Membranes.-Applied for 24 hours on a soaked rag or painted daily for 28 days, dimethylformamide had no more than a transient slightly irritant effect on human skin. Instilled into the conjunctival sac of the rabbit a $25 \%$ solution had no effect; $50 \%$ was slightly irritant and 75 to $100 \%$ produced a more severe inflammation.

\section{Discussion}

These experiments show dimethylformamide to be of intermediate toxicity by comparison with

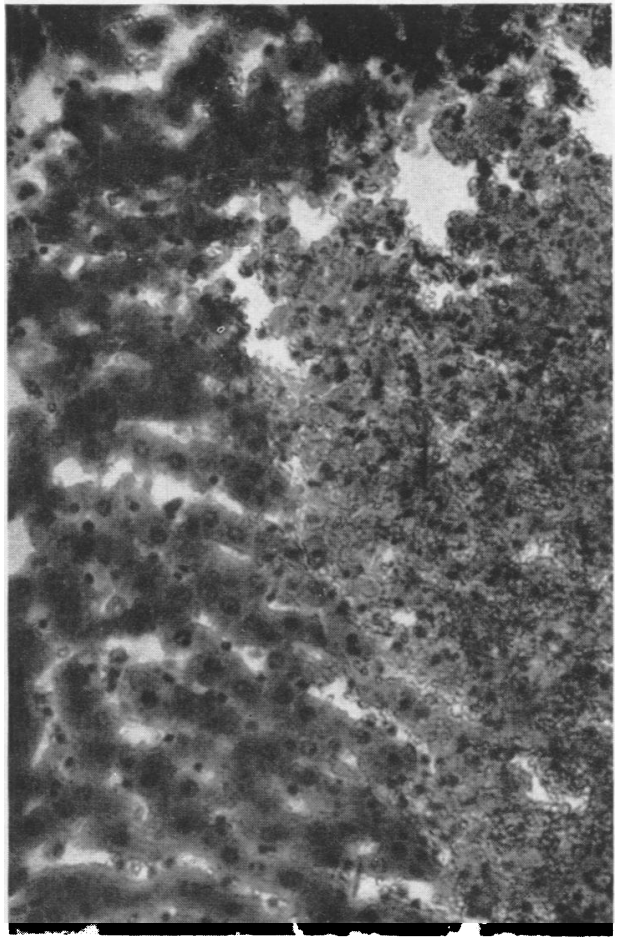

FIG. 3.-The same liver starved for fat showing the sharp line of demarcation between surviving and necrotic liver with the cells containing fat. $\times 125$.

other solvents in common use. The toxic effects are similar in all the species tested though fish seem surprisingly resistant. The reactions of repeated exposure by inhalation are essentially the same as those seen in acute poisoning.

The most striking lesion is the damage to the liver with an associated loss of weight and anorexia. The rise in blood sugar seen in the early stages of poisoning cannot readily be explained. There is probably no primary disturbance of the carbohydrate metabolism and the pancreas shows no histological evidence of damage. Similar changes in blood sugar may be seen in CO poisoning (Moeschlin, 1939) and toluene poisoning (Dimitrenko, 1954).

The changes in the E.C.G. and the deposition of iron in the spleen are probably non-specific and may be observed in animals poisoned by a number of different substances.

The damage to the kidney seen in chronically poisoned animals might be primary or a secondary sign of general poisoning. There is a similarity between the chemical and toxicological properties of dimethylformamide and dimethylnitrosamine. The latter substance also causes widespread liver 
necrosis in laboratory animals (Barnes and Magee, 1954). But haemorrhages in the gut and peritoneum were observed only in animals poisoned with dimethylnitrosamine. Carbon tetrachloride also damages both the liver and kidney. It is impossible to say whether the similarity between the action of carbon tetrachloride and dimethylformamide is purely one of chance or that it can be explained by a similarity in their metabolism and mode of action in the body.

\section{Summary}

Dimethylformamide is used as a solvent for polyacrylonitrile. It is moderately toxic to rats, mice, rabbits, and cats with an L.D.50 of 0.14 to $0.37 \mathrm{ml} . / 100 \mathrm{~g}$. body weight for rats, depending on the route of application. Death took place up to 12 days after a single dose and liver damage is the most prominent feature with some accompanying kidney damage. Dimethylformamide does not irritate the skin or mucous membranes but can be absorbed through the intact skin of the rat. Some is excreted unchanged in the urine.

Repeated doses by inhalation showed rats to be unaffected by concentrations up to 420 p.p.m., while cats were upset by concentrations of 100 p.p.m.

\section{REFERENCES}

Barnes, J. M., and Magee, P. N. (1954). British Journal of Industrial Medicine, 11, 167

Bergmann, F. (1952). Analyt. Chem., 24, 1367.

Dimitrenko, M. T. (1954). Farmakol. i. Toksikol., 17, 39.

Kärber, G. (1931). Arch. exp. Path. Pharmak., 162, 480.

Kärber, G. (1931). Arch. exp. Path. Pharmak., 162, 